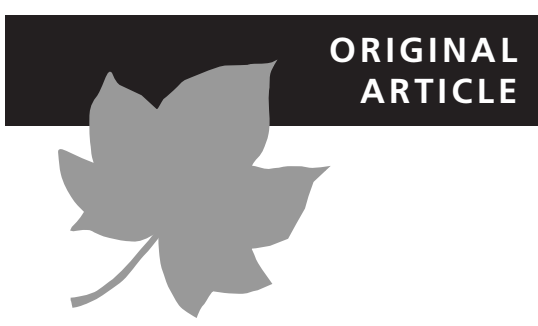

\title{
Testing phylogenetic hypotheses for reconstructing the evolutionary history of Dolichopoda cave crickets in the eastern Mediterranean
}

Giuliana Allegrucci ${ }^{1 \star}$, Mauro Rampini ${ }^{2}$, Paolo Gratton ${ }^{1}$, Valentina Todisco ${ }^{1}$ and Valerio Sbordoni ${ }^{1}$

${ }^{1}$ Department of Biology, University of Rome Tor Vergata and ${ }^{2}$ Department of Animal and Human Biology, University of Rome La Sapienza, Rome, Italy
${ }^{\star}$ Correspondence: Giuliana Allegrucci, Dipartimento di Biologia, Università di Roma Tor Vergata, via Della Ricerca Scientifica, 00133 Rome, Italy.

E-mail: allegrucci@uniroma2.it

\begin{abstract}
Aim To investigate the molecular phylogenetic divergence and historical biogeography of cave crickets belonging to the genus Dolichopoda (Orthoptera, Rhaphidophoridae).
\end{abstract}

Location Caves in continental and insular Greece.

Methods We sequenced 1967 bp of mitochondrial DNA, corresponding to three fragments of the small and large subunit of the ribosomal RNA (16S and 12S rRNA, respectively) and to the subunit I of cytochrome oxidase (COI), to reconstruct phylogenetic relationships among all 30 known Greek species of Dolichopoda. Alternative hypotheses about the colonization of the Hellenic Peninsula by Dolichopoda species were tested by comparing the degree of discordance between species trees and gene trees under four plausible biogeographical scenarios.

Results The present study revealed a rather well resolved phylogeny at species level, identifying a number of clades that represent long-separated lineages and diverse evolutionary histories within the genus Dolichopoda. Two main clades were revealed within Hellenic-Aegean species, identifying a north-western and a south-eastern species group. Based on Bayesian analysis, we applied a relaxed molecular clock to estimate the divergence times between the lineages. The results revealed that the origins of eastern Mediterranean lineages are much older than those of previously studied western Mediterranean Dolichopoda. Tests of alternative biogeographical hypotheses showed that a double colonization of the Hellenic Peninsula, following separate continental and trans-Aegean routes during the Messinian stage, best accounts for the present distribution of Greek Dolichopoda species.

Main conclusions Reconstruction and biogeographical hypothesis testing indicated that the colonization of Greece by Dolichopoda species comprised two episodes and two different routes. The southern lineage probably arose from a transAegean colonization during the Messinian salinity crisis (5.96-5.33 Ma). The northern lineage could be the result of dispersal from the north through the Balkan Peninsula. The opening of the Mid-Aegean Trench could have promoted an initial diversification within the uprising Anatolian Plateau, while the Messinian marine regression offered the conditions for a rapid dispersal through the whole AegeanHellenic region. In addition, climatic events during the Plio-Pleistocene may have been responsible for the speciation within each of the two different phylogeographical units, principally attributable to vicariance events.

\section{Keywords}

Biogeography, cave crickets, divergence times, Dolichopoda, east Mediterranean, mitochondrial DNA, Orthoptera, phylogeography. 


\section{INTRODUCTION}

The reconstruction of phylogeny is an essential first step towards understanding the biogeography of a group. In recent years several genetic studies of invertebrates and vertebrates, distributed in continental and insular Greece, have attempted to relate molecular divergence with major palaeogeographical events that occurred in the eastern Mediterranean region. They have been mostly focused on the Aegean Archipelago because of its high levels of diversity and endemism (Strid, 1997; Sfenthourakis \& Legakis, 2001) and its complex palaeogeographical history (Dermitzakis, 1990). The geological evolution of the Balkan Peninsula has been largely driven by the collision of the African and Arabian plates with the Eurasian Plate beginning during the middle Miocene [16 million years ago, (Ma); Steininger \& Rögl, 1984; Krijgsman, 2002]. The Hellenic area in particular shows an intricate geological history with a series of land connection events through the late Tertiary. These geological events, together with the Quaternary palaeoclimatic cycling, are likely to have contributed to the distribution and diversification of many terrestrial animals (Beerli et al., 1996; Douris et al., 1998; Oliverio et al., 2000; Fattorini, 2002; Parmakelis et al., 2006a,b).

In this study we analysed phylogenetic relationships of eastern Mediterranean cave crickets species belonging to the genus Dolichopoda Bolivar, 1880, a Mediterranean genus distributed from the eastern Pyrenees to Turkish Armenia and the Caucasus Mountains. Dolichopoda Bolivar 1880 consists of more than 45 species and belongs to the family Rhaphidophoridae (Orthoptera, Rhaphiolophozoidea), which includes a large number of cave-adapted genera and species with world-wide distribution. Several species also occur in epigean habitats, being mostly forest dwellers in tropical areas. Caveadapted species occur in temperate Holarctic, Afrotropical, Neotropical and Australian regions and they are thought to derive from sylvicolous ancestors (Leroy, 1967; Hubbell \& Norton, 1978; Di Russo \& Sbordoni, 1998). Fossil representatives of such fauna have been recorded in Europe from Baltic ambers dating back to the middle Eocene. Species within the Mediterranean genera Troglophilus and Dolichopoda are thought to originate from such ancestors (Chopard, 1936). However, phyletic relationships within the Rhaphidophoridae are controversial (Gorochov, 2001). Most species of Dolichopoda are strictly dependent upon caves, although, especially in the northern part of the range, where favourable climatic conditions are encountered, several populations inhabit cavelike habitats such as ravines and rock-fissures, and individuals are often observed outside in moist or mesic woods. Different bioclimatic and vegetational conditions are found in the southeastern part of their range, where the dry hot Mediterranean 'macchia' dominates, characterizing most of the Hellenic area. In this environment, Dolichopoda species are occasionally observed out of caves, but only at night. We might therefore expect that gene flow among the Hellenic cave populations could be more limited than that occurring between populations living in the northern part of the range.
Today, the highest Dolichopoda species diversity is found in insular and peninsular Greece, where 24 Dolichopoda species occur. Dolichopoda species are found from Macedonia to the Peloponnesus, with several insular species on the Ionian and Aegean islands. The spatial range of each species is, however, restricted and often limited to a single cave (Boudou-Saltet, 1980). Several populations considered in this paper have been found in 'new' localities and probably represent new species.

In this paper we analysed 24 known species and six recently sampled, unclassified populations of Dolichopoda, ranging across continental Greece. Insular species from the Ionian and Aegean seas and one more species from Anatolia were also considered (Table 1, Fig. 1). We sequenced 1967 bp of mitochondrial DNA, representing three fragments of the small and large subunit of ribosomal RNA (16S and $12 \mathrm{~S}$ rRNA, respectively) and subunit I of cytochrome oxidase (COI). To understand the relationships of the Balkan Dolichopoda species within the genus Dolichopoda we included in the analyses species previously analysed by Allegrucci et al. (2005), namely Dolichopoda linderi (Dufour, 1861), from the Pyrenees and three additional taxa, Euhadenoecus insolitus Hubbell, 1978, Hadenoecus cumberlandicus Hubbell \& Norton, 1978 and Troglophilus cavicola (Kollar, 1833), belonging to three different genera within the family. These genera are considered the closest living relatives to the genus Dolichopoda (Hubbell \& Norton, 1978).

Applying well-assessed substitution rates previously considered for the same genes in the western Mediterranean Dolichopoda (Allegrucci et al., 2005), we performed a Bayesian analysis assuming a relaxed molecular clock (Drummond et al., 2006) to estimate a dated phylogeny of the Greek Dolichopoda. Alternative biogeographical hypotheses (based on the detailed palaeogeographical data available for the Aegean region) were explicitly tested to determine the most plausible scenario that may explain the current distributional pattern of eastern Dolichopoda species. In particular, we address the following issues:

1. What is the time frame of the major cladogenetic events in eastern Mediterranean Dolichopoda?

2. What are the respective roles of vicariance and dispersal in shaping the distributional pattern of Dolichopoda lineages in the region?

3. How did the palaeogeographical history of the eastern Mediterranean region influence the distribution patterns of Dolichopoda lineages?

\section{MATERIALS AND METHODS}

\section{Taxon sampling}

Forty populations belonging to 30 species of the genus Dolichopoda from the eastern Mediterranean area were sampled in this study. Specimens were preserved in $90 \%$ ethanol. Three additional taxa belonging to three different genera within the same family were used as outgroups (Troglophilus cavicola, Hadenoecus cumberlandicus and Euhadenoecus insolitus; Table 1). All known Balkan species of Dolichopoda were 
Table 1 Dolichopoda species and outgroup taxa included in this study.

\begin{tabular}{|c|c|c|c|}
\hline & Localities & Code & GenBank accession no. \\
\hline \multicolumn{4}{|l|}{ Outgroups } \\
\hline Troglophilus cavicola & Covoli di Velo Caves, Veneto, northern Italy & TRO & 12S:EF216946 16S:AY793564 COI:AY793624 \\
\hline Hadenoecus cumberlandicus & $\begin{array}{l}\text { Bat Cave, Carter Cave State Park, Carter Co., } \\
\text { KY, USA }\end{array}$ & BAT & 12S:EF216948 16S:AY793562 COI:AY793592 \\
\hline Euhadenoecus insolitus & Indian Grave Point Cave, De Kalb Co., TN, USA & IND & 12S:EF216947 16S:AY793563 COI:AY793591 \\
\hline \multicolumn{4}{|l|}{ Genus Dolichopoda } \\
\hline \multicolumn{4}{|l|}{ France (west Mediterranean) } \\
\hline D. linderi & $\begin{array}{l}\text { Sirach Cave Eastern Pyrenees, south- } \\
\text { western France }\end{array}$ & SIR & 16S:AY793567 COI:AY793598/AY793599 \\
\hline \multicolumn{4}{|l|}{ Croatia } \\
\hline \multirow[t]{2}{*}{ D. araneiformis } & Velika Cave, Blato, Miljet & VEL & 12S:EF216944 16S:EF216967 COI:EF217019 \\
\hline & Kod Solina Cave, Govedari, Miljet & SOL & 12S:EF216944 16S:EF216967 COI:EF217018 \\
\hline \multicolumn{4}{|l|}{ Northern Greece } \\
\hline \multirow[t]{2}{*}{ D. remyi } & Pozarska Mala Pestera, Loutrakiou, Pella & POZ & 12S:EF216939 16S:EF216969 COI:AY793637 \\
\hline & Waterfall Cave, Edessa, Pella & EDE & 12S:EF216939 16S:EF216969 COI:AY793637 \\
\hline \multirow[t]{2}{*}{ D. hussoni } & Apano Skala Cave, Naoussa, Imathia & IZB & 12S:EF216943 16S:EF216973 COI:EF217031 \\
\hline & Saranda Outdate Cave, Naoussa, Imathia & NAU & 12S:EF216943 16S:EF216973 COI:EF2217032/3/4 \\
\hline \multirow[t]{2}{*}{ D. annae } & Aghlia Paraskevi Cave, Tembi Valley, Larissa & TEM & 12S:EU887846 16S:EU887861 COI:EU887894/5/6 \\
\hline & Small caves, Kato Olimpos, Leptokaria, Kalipefki & OLI & 12S:EU887845 16S:EU887860 COI:EU887891/2/3 \\
\hline D. thasosensis & Drakotripa Cave, Panayia, Thasos Island, Kavala & DRA & 12S:EF216926 16S:EF216956 COI:EF217020/1 \\
\hline D. graeca & Perama Cave, Ioannina, Epiro & PER & 12S:EF216923 16S:EF216953 COI:EF217013 \\
\hline \multicolumn{4}{|l|}{ Ionian Islands } \\
\hline D. steriotisi & Antropograva Cave, Klimatia, Kerkira, Corfu & ANT & 12S:EF216925 16S:EF216955 COI:EF217016/7 \\
\hline D. gasparoi & Chirospilia Cave, Evghiros, Levkada & $\mathrm{CHI}$ & 12S:EF216920 16S:EF216950 COI:EF217008/9 \\
\hline D. ithakii & Marmarospilia cave, Vathi, Ithaki Island & ITA & 12S:EF216919 16S:EF216949 COI:EF217006/7 \\
\hline D. patrizii & Small cave, Petalas & PET & 12S:EU887847 16S:EU887862 COI:EU887898/9/900 \\
\hline D. pavesii & Drogarati Cave, Sami, Kefalonia Island & SPI & 12S:EF216921 16S:EF216951 COI:EF217010/1 \\
\hline \multicolumn{4}{|l|}{ Central-Western Greece } \\
\hline D. giachinoi & $\begin{array}{l}\text { Megalospilio Cave, Monastirakion, } \\
\text { Aitolo-Akarnania }\end{array}$ & ORO & 12S:EF216922 16S:EF216952 COI:EF217012 \\
\hline D. kiriakii & Kiriaki Cave, Korifè, Aghlia Kiriaki, Parga & AGH & 12S:EF216924 16S:EF216954 COI:EF217014/5 \\
\hline D. lustriae & $\begin{array}{l}\text { Aghios Andreas Cave, Valtou M., Halkiopuli, } \\
\text { Etolia }\end{array}$ & AND & 12S:EU887848 16S:EU887863 COI:EU887878 \\
\hline \multicolumn{4}{|l|}{ Central-Eastern Greece } \\
\hline D. sp. 'Parnaso' & Korykion Andron Cave, Mount Parnitha, Attica & KOR & 12S:EU887851 16S:EU887866 COI:EU887905/6 \\
\hline \multirow[t]{2}{*}{ D. vandeli } & Hermes Cave, Orkomenos, Dhionisos, Beotia & HER & 12S:EF216932 16S:EF216962 COI:EF217039/40 \\
\hline & Cave over Kopais Lake, Orkomenos, Beotia & GLK & 12S:EF216932 16S:EF216962 COI:EF217038 \\
\hline D. insignis & Panos Cave, Marathon, Athene, Attica & PAN & 12S:EF216938 16S:EF216968 COI:EF217054 \\
\hline D. petrochilosi & Aghlia Joannis, Nea Pendeli, Athene, Attica & JOA & 12S:EF216937 16S:EF216967 COI:EF217053/1/2 \\
\hline D. cassagnaui & Aghlia Triada Cave, Karistos, Eubea Island & TRI & 12S:EF216931 16S:EF216961 COI:EF217035/6/7 \\
\hline \multirow[t]{2}{*}{ D. makrykapa } & Paralia Kilidau Cave, Lamari, Eubea Island & PKI & 12S:EF216941 16S:EF216971 COI:EF217942 \\
\hline & $\begin{array}{l}\text { Paralia Pot Cave, Kao Seta, Aghlia Triada, } \\
\text { Eubea Island }\end{array}$ & KSA & 12S:EF216941 16S:EF216971 COI:EF217041 \\
\hline \multicolumn{4}{|l|}{ Eastern Greek Islands } \\
\hline \multirow[t]{2}{*}{ D. naxia } & Zeus Cave, Filotas, Naxos Island, Cyklades & ZEU & 12S:EU887853 16S:EU887868 COI:EU887909/10/11 \\
\hline & small Cave, Stauros, Naxos Island, Cyklades & STA & 12S:EU887852 16S:EU887867 COI:EU887908 \\
\hline D. sp. ‘East Aegean’ & Moni Spilianis Cave, Pithagorion, Samos Island & SPS & 12S:EF216935 16S:EF216965 COI:EF217049 \\
\hline D. sp. 'East Aegean' & $\begin{array}{l}\text { Seven Virgins Cave, Kalimnos, Kalimnos Island, } \\
\text { Dodecanese }\end{array}$ & EPT & 12S:EF216933 16S:EF216963 COI:EF217047 \\
\hline D. sp. 'East Aegean' & $\begin{array}{l}\text { Skalia cave, Skalia, Kalimnos Island, } \\
\text { Dodecanese }\end{array}$ & SKA & 12S:EF216934 16S:EF216964 COI:EF217048 \\
\hline \multicolumn{4}{|l|}{ Northern Peloponnesus } \\
\hline \multirow[t]{2}{*}{ D. matsakisi } & Analipsi Cave, Pititsa, Achaia & ANA & 12S:EF216927 16S:EF216957 COI:EF217022/3 \\
\hline & Ton Limnon Cave, Kastri, Kalavrita, Achaia & KAS-A & 12S:EF216927 16S:EF216957 COI:EF217024 \\
\hline D. sp. 'Limnon' & Ton Limnon Cave, Kastri, Kalavrita, Achaia & KAS-B & 12S:EF216928 16S:EF216958 COI:EF217025 \\
\hline D. dalensi & Kefalovrisi Cave, Argos, Argolide & KEF & 12S:EF216929 16S:EF216959 COI:EF217026 \\
\hline
\end{tabular}


Table 1 Continued.

\begin{tabular}{clll}
\hline & Localities & Code & GenBank accession no. \\
\hline $\begin{array}{c}\text { Southern Peloponnesus } \\
\text { D. unicolor }\end{array}$ & & & \\
& $\begin{array}{l}\text { Kataphingi Cave, Selitsa, Messenia } \\
\text { River cave of Glyfada, Dirou, Aeropolis, Laconia }\end{array}$ & KAT & 12S:EF216940 16S:EF216970 COI:EF217045/6 \\
D. sp. 'Taygeto' & $\begin{array}{l}\text { Aghia Varvara Cave, Parori, Sparta, Lakonia } \\
\text { (Taygeto Mt) }\end{array}$ & VAR & 12S:EF216940 16S:EF216970 COI:EF217043/4 \\
& Taygeto Shelter,Parori, Sparta, Lakonia & TAY & 12S:EU887850 16S:EU887865 COI:EU887904 \\
Crete Island & Aghlia Paraskevi Cave, Skotinon, Iraklio & & \\
D. paraskevi & Atzigano cave, Adrianos, Lassithi & PAR & 12S:EF216942 16S:EF216972 COI:EF217027/8 \\
D. sp. 'Crete' & Dikteion Antron Cave,Psychro, Iraklio & NIK & 12S:EF216942 16S:EF216972 COI:EF217030 \\
Turkey & & DHI & 12S:EF216930 16S:EF216960 \\
D. sbordonii & Karain Cave, Antalya, Turkey & & COI:217029 \\
\hline
\end{tabular}

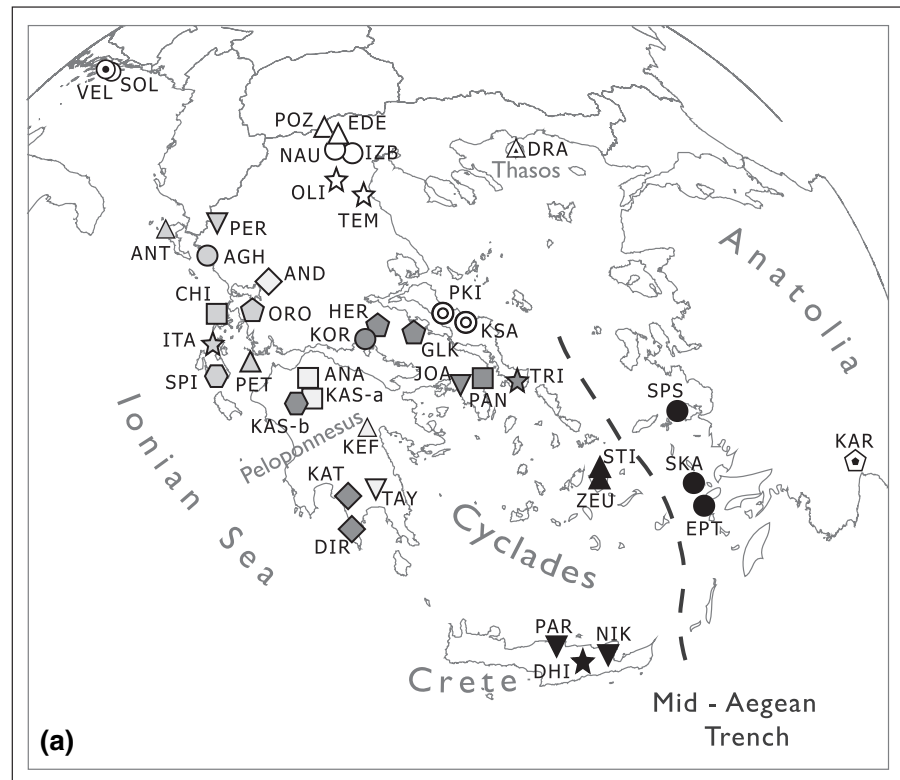

Projection:Vertical Near-Side Perspective

Central Meridian: $22.90 \mathrm{E}$

Reference Latitude: $37.13 \mathrm{~N}$

Height of Viewpoint: $100000 \mathrm{~m}$

Scale varies in this perspective

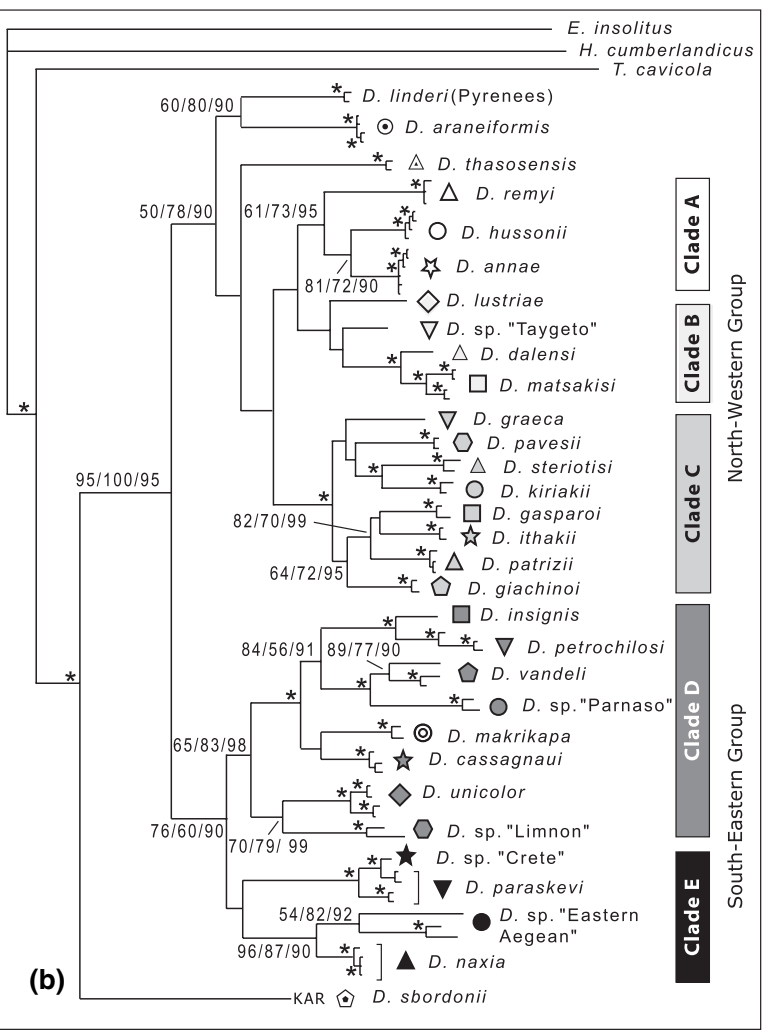

Figure 1 (a) Sampling sites of the Greek Dolichopoda species studied. Different symbols indicate different species (see Table 1 for a definition of the codes). (b) Relationships among species of Dolichopoda, inferred by Bayesian analysis from mtDNA sequences. Values above the branches indicate bootstrap percentage for maximum parsimony (MP), maximum likelihood (ML) methods and posterior probabilities (PP) derived from Bayesian analysis, respectively. Asterisks above the branches indicate bootstrap values equal to 90 both for MP and ML analyses and PP values equal to 99.

included in this study: Dolichopoda araneiformis (Burmeister, 1838) from Croatia, Dolichopoda remyi Chopard, 1934, Dolichopoda hussoni Chopard, 1934, Dolichopoda annae Boudou-Saltet, 1973, Dolichopoda thasosensis Chopard, 1964 and Dolichopoda graeca Chopard, 1964 from northern Greece; Dolichopoda steriotisi Boudou-Saltet, 1972, Dolichopoda gaspa- roi Rampini \& Di Russo, 2008, Dolichopoda ithakii Rampini \& Di Russo, 2008, Dolichopoda patrizii Chopard, 1964, Dolichopoda pavesii Galvagni, 2002 from the Ionian Islands; Dolichopoda giachinoi Rampini \& Di Russo, 2008, Dolichopoda kiriakii Rampini \& Di Russo, 2008 and Dolichopoda lustriae Rampini \& Di Russo, 2008 from central-western Greece; Dolichopoda 
vandeli Boudou-Saltet, 1970, Dolichopoda sp. 'Parnaso', Dolichopoda insignis Chopard, 1955, Dolichopoda petrochilosi Chopard, 1954, Dolichopoda cassagnaui Boudou-Saltet, 1980 and Dolichopoda makrykapa Boudou-Saltet, 1980 from centraleastern Greece; Dolichopoda naxia Boudou-Saltet, 1972 and Dolichopoda sp. 'East Aegean' from the eastern Greek Islands Samos and Kalimnos; Dolichopoda matsakisi Boudou-Saltet, 1972, Dolichopoda sp. 'Limnon' and Dolichopoda dalensi Boudou-Saltet, 1972 from northern Peloponnesus; Dolichopoda unicolor Chopard, 1964 and Dolichopoda sp. 'Taygeto' from southern Peloponnesus; Dolichopoda paraskevi BoudouSaltet, 1973 and Dolichopoda sp. 'Crete' from Crete Island. One species from south-west Anatolia was considered (Dolichopoda sbordonii Di Russo \& Rampini, 2006; Table 1, Fig.1).

\section{DNA extraction, amplification and sequencing}

Genomic DNA was isolated from leg muscle using a cetyl trimethyl ammonium bromide (CTAB) protocol (Doyle \& Doyle, 1987). Liquid nitrogen was used during the homogenization phase. Three mitochondrial genes (COI, 16S rDNA and $12 \mathrm{~S}$ rDNA) were used in this study.

Two overlapping fragments of the cytochrome oxidase I gene (COI, total of $969 \mathrm{bp}$ ), a 527-bp fragment of the $16 \mathrm{~S}$ rRNA gene and a 400-bp fragment of the $12 \mathrm{~S}$ rRNA were amplified through the polymerase chain reaction (PCR) from each individual sample. The primers used were J1751, N2191 (Simon et al., 1994), UEA1, UEA5, UEA8 and UEA10 (Lunt et al., 1996) for the COI gene, 16Sa (Kocher et al., 1989) and 16Sb (Palumbi, 1996) for the 16S rRNA gene, and 12Sai and 12Sbi (Simon et al., 1994) for the 12S rRNA.

Double-stranded amplifications were performed with a Perkin-Elmer-Cetus thermal cycler (PE Applied Biosystems, Foster City, CA, USA) in a $25-\mu \mathrm{L}$ reaction volume containing genomic DNA (10-100 ng), $1.5 \mathrm{~mm} \mathrm{MgCl}_{2}, 2.5 \mathrm{~mm}$ of each nucleotide (dNTP), $0.5 \mu \mathrm{M}$ primer, $1 \mathrm{U}$ of Amplitaq (Applied Biosystems, Foster City, CA, USA) and the buffer supplied by the manufacturer. Optimal cycling parameters varied for each primer pair used and are the same as in Allegrucci et al. (2005). The PCR products were purified using the ExoSAP digestion (GE Healthcare Europe, Munich, Germany), directly sequenced in both directions using the BigDye Terminator Ready reaction kit, and resolved on an ABI 3100 Genetic Analyzer (PE Applied Biosystems), following the manufacturer's protocols. Sequence data were edited and compiled using CODOnCOde ALIGner (Codoncode Corporation MA, USA version 2.0.2). All sequences were submitted to GenBank (accession numbers are reported in Table 1).

\section{Sequence alignment and analysis}

Each gene fragment (12S, $16 \mathrm{~S}$ and COI) was considered separately for the alignment. Sequences of $16 \mathrm{~S}$ and $12 \mathrm{~S}$ rRNA were aligned using ClustalX 1.81 (Thompson et al., 1997) with opening gap $=10$ and extending gap $=0.10$. The alignment, also checked by eye, did not require further improve- ment by considering a secondary structure model. The COI nucleotide sequences were assembled, aligned, and translated with CODONCODE ALIGNER 2.0.2.

The three mitochondrial genes were treated as separate data partitions for phylogenetic analyses. Congruence among partitions was assessed by the partition-homogeneity test [also named the incongruence length difference (ILD) test; Farris et al., 1994, 1995], as implemented in PAUP ${ }^{*}$. All data sets were subsequently combined for a total evidence analysis.

Maximum parsimony (MP; Farris, 1970) was also performed with PAUP ${ }^{\star}$ (Swofford, 2003). The MP trees were inferred with a heuristic search using stepwise addition of taxa with 10 random replications and ACCTRAN character-state optimization. Gaps were treated as missing data. The consistency index (CI; Kluge \& Farris, 1969), calculated after the exclusion of uninformative characters (Sanderson \& Donoghue, 1989), was used to examine overall level of homoplasy. MP searches were run with all substitutions unweighted or with weighting of transversions (Tv) (only the third position for the COI data set) five times as much as the transitions ( $\mathrm{Ti}$, analysis available from the authors). To estimate statistical support for branches, bootstrap analysis with 1000 replicates was conducted in MP analysis.

Likelihood-ratio tests implemented in the program MODELTEST version 3.07 (Posada \& Crandall, 1998) were used to choose the best-fit model and estimate parameters for each data partition (Table 2). Maximum-likelihood (ML) analyses were performed with a mixed model using TREEFINDER (Jobb et al., 2004), in which the data were partitioned by gene into three parts corresponding to the different gene fragments, each with its own optimized parameters for a general timereversible (GTR) model with invariant sites and among-site variation $(\mathrm{GTR}+\mathrm{I}+\Gamma$; Lanave et al., 1984; Yang, 1994; Gu et al., 1995). Bootstrap support values for ML analysis were also calculated using TREEFINDER with 1000 replicates.

A Bayesian analysis was performed using MRBAYEs version 3.0 (Ronquist \& Huelsenbeck, 2003). DNA sequence data were partitioned by gene, as in TREEFINDER ML analysis. The substitution model was the $\mathrm{GTR}+\mathrm{I}+\Gamma$ for each partition. Bayesian analysis was performed using four search chains for 2,000,000 generations, sampling trees every 100 generation. The first 2000 trees were discarded as burn-in. Parameter stability was estimated by plotting log-likelihood values against generation time, and a consensus tree with posterior probabilities was then generated in PAUP*

Table 2 General time-reversible (GTR) model parameters: substitution matrix, site rate heterogeneity $(\alpha)$ and percentage of invariant sites (I) for each analysed gene (COI and 16S/12S rRNA) of Greek species of Dolichopoda.

\begin{tabular}{lrrrrrrrr}
\hline Gene & A-C & A-G & A-T & C-G & C-T & G-T & $\alpha$ & I \\
\hline COI & 1.763 & 10.552 & 6.111 & 1.264 & 31.818 & 1 & 0.761 & 0.457 \\
$12 S$ & 3.837 & 17.995 & 10.601 & 1.549 & 89.027 & 1 & 0.602 & 0.516 \\
$16 S$ & 5.841 & 5.322 & 11.129 & 0 & 53.497 & 1 & 0.483 & 0.533 \\
\hline
\end{tabular}


Eleven competing phylogenetic hypotheses were tested using the approximately unbiased (AU; Shimodaira, 2002) tree selection test in the software package CONSEL (Shimodaira \& Hasegawa, 2001). For comparison, we also performed the Shimodaira-Hasegawa test (SH; Shimodaira \& Hasegawa, 1999). A Mantel test (Mantel, 1967), considering all ingroup taxa and the combined data sets, was carried out to assess possible correlation between genetic and geographical distances.

\section{Dating of the cladogenetic events}

A likelihood ratio test (LRT) was used to test the molecular clock hypothesis, according to Huelsenbeck \& Crandall (1997). The LRT results suggested a heterogeneous rate variation for each gene and therefore a clocklike evolution of sequences could not be assumed. Consequently, dates of divergence were inferred using a relaxed molecular clock, following the uncorrelated relaxed lognormal clock as implemented in BEAST (version 1.4.6, Drummond \& Rambaut, 2007). A Yule or 'pure birth' prior process was also applied to model speciation. The time to the most recent common ancestor (MRCA) between each clade was estimated under the model parameters highlighted in modeltest (Posada \& Crandall, 1998). This analysis was carried out on COI and on $12 S / 16 S$, separately and on the concatenated matrix. For each data set, we did two independent runs with BEAST, each one for 10 million steps. One million steps were discarded as burn-in. Convergence to stationarity and effective sample size (ESS) of model parameters were assessed using TRACER 1.4 (Rambaut \& Drummond, 2003).

Fossil evidence or adequate events of geological vicariance to calibrate the molecular clock were not available. Hence, we applied the substitution rates reported in the literature for insect mitochondrial COI, $12 \mathrm{~S}$ and $16 \mathrm{~S}$ to approximate absolute ages of divergence among haplotypes. The mean rates used in this study were COI $=1.2 \%$ per lineage per million years (Myr; Brower, 1994; Buckley et al., 2001; Caccone \& Sbordoni, 2001) and $12 \mathrm{~S} / 16 \mathrm{~S}=0.7 \%$ per lineage per $\mathrm{Myr}$ (Brower, 1994). For the concatenated data set we used the weighted mean between these two values.

\section{Test of biogeographical hypotheses}

We tested alternative hypotheses about the colonization of the Hellenic Peninsula by Dolichopoda species by comparing the degree of discordance between species trees and gene trees.

First, species trees were designed to represent the expected splitting sequence and timing under four plausible biogeographical scenarios. The degree of discordance expected by chance alone was assessed by simulating 1000 coalescent gene trees contained within each of the hypothesized species trees. The number of deep coalescences (Maddison, 1997) was then calculated in MEsquite 2.5 (Maddison \& Maddison, 2008) for the simulated trees and for 5000 gene trees sampled from the stationary phase of the Markov chain Monte Carlo (MCMC) analysis performed in BEAST using concatenated COI and 12S/ $16 \mathrm{~S}$ sequence data. Our approach compares the frequency distribution of the number of deep coalescences which is expected in the case where the biogeographical hypothesis is true with the frequency distribution 'observed' in an informed sample of trees (representative of the posterior distribution of gene genealogies given the data). The overlapping area of the two frequency distributions accounts for the similarity between them: therefore, in the case where this area includes $<5 \%$ of the cases in each frequency distribution, then the null hypothesis (the two distributions coincide) can be rejected. The number of deep coalescences expected by chance increases with population size, so that choosing appropriate assumptions for effective female population size $\left(N_{\mathrm{f}}\right)$ is critical to the effectiveness of our approach. In fact, published markrecapture estimates (Carchini et al., 1983) indicate that Dolichopoda census population size tends to be very small $(<4000)$. In order to minimize the probability of rejecting a true hypothesis (type I error), we performed distinct simulations assuming a conservative $N_{\mathrm{f}}=10,000$ and a highly conservative $N_{\mathrm{f}}=50,000$ per lineage.

The use of a Bayesian posterior sample of gene trees instead of a single estimated phylogeny (for example ML phylogeny) allowed us to account for uncertainties in phylogenetic reconstruction. Also, since gene trees produced by BEAST have branch lengths in units of time, we were able to test explicitly the time-frame of biogeographical hypotheses by assuming a mean generation time of two generations per year, according to Di Russo et al. (1987).

\section{RESULTS}

\section{Genetic data analyses}

The three mitochondrial genes here considered (i.e. 12S/16S rRNA and COI) consisted of 404, 550 and 964 aligned nucleotides, respectively. In each gene, nucleotide composition was clearly biased towards A-T. Sequences were obtained for each individual and a total of 88 samples were analysed.

For the 12S rRNA gene fragment, sequence divergence ranged from $1.2 \%$ to $19.4 \%$ between species and from $0 \%$ to $2 \%$ within species. Among all considered species, 133 sites were variable and 102 were parsimony informative. The transition/transversion ( $\mathrm{Ti} / \mathrm{Tv}$ ) ratio ranged from 14 to 0.4 . Ti values accounted for about $56 \%$ or $59 \%$ of all substitutions, when outgroups were included or excluded, respectively. The $16 \mathrm{~S}$ gene fragment showed a percentage of sequence divergence ranging from $11.4 \%$ to $0.2 \%$ between species and from $1.8 \%$ to $0 \%$ within species. Among all considered species, 151 sites were variable and 118 were parsimony informative. The Ti/Tv ratio ranged from 7 to 0 and $\mathrm{Ti}$ values accounted for about $42 \%$ of all substitution, with outgroups either included or excluded. The percentage divergence in the COI gene ranged from $18.4 \%$ to $0.1 \%$ in interspecific comparisons and from $4.1 \%$ to $0 \%$ in the intraspecific ones. Among all considered 
species 390 sites were variable and 310 were parsimony informative. The Ti/Tv ratio ranged from 20 to 0 . Ti values accounted for about $54 \%$ of all substitutions, if outgroups were included, and for $56 \%$ if they were excluded.

The partition-homogeneity test did not reject the null hypothesis that COI, $12 \mathrm{~S}$ and $16 \mathrm{~S}$ rRNA data sets were any different from random partitions of the pooled data $(P>0.05)$. Thus, we combined the three data sets for all subsequent analyses. The combined data set included 1967 sites, 674 of which were variable and 530 were parsimony informative.

As reported in the Materials and Methods section, MODELTEST indicated that the general time reversible model was most optimal with among-site rate heterogeneity and the proportion of invariant sites for each of the three gene fragments analysed (Table 2).

\section{Phylogenetic analyses}

Analysis of the combined data sets under unweighted parsimony resulted in 16 equally short trees with length $(L)=2119$ steps (homoplasy index $=0.555$; consistency index $=0.444$, retention index $=0.766$ ). One tree with $\ln L=-13,126.26$ was recovered under ML analysis. The Bayesian analysis produced consensus topology highly congruent with those obtained by ML and MP analyses. Figure 1 shows the tree obtained under Bayesian analysis.

Within the Greek species two main groups could be distinguished (Fig. 1), identifying the north-western and south-eastern species, respectively. The north-western group included three clades (A, B, C). Clade A was represented by the northernmost species (D. remyi, D. hussoni and D. annae). Dolichopoda thasosensis from Thasos Island in northern Greece was basal to this clade, but its relationships were not resolved. Clade B included the westernmost species from continental and insular Greece (D. graeca, D. kiriakii, D. steriotisi, D. pavesii, D. gasparoi, D. ithakii, D. patrizii and D. giachinoi). Clade C included species from north and south Peloponnesus (D. dalensi, D. matsakisi and an undescribed species, 'Taygeto', respectively) linked to $D$. lustriae from the Valtou Mountains, in central-western Greece. Each of these three clusters was strongly supported, with bootstrap (BP) values ranging from $73 \%$ to $100 \%$ and posterior probability (PP) values ranging from $95 \%$ to $98 \%$. Dolichopoda araneiformis from Croatia clustered together with $D$. linderi from the Pyrenees, as basal to the entire north-western group.

The south-eastern group included two clades (D, E; Fig. 1). Clade D comprised two subclades, one represented by the eastern species (D. insignis, D. petrochilosi, D. vandeli, D. makrikapa and D. cassagnaui) and the other one by the southernmost species (D. unicolor) from south Peloponnesus. The sister taxon of the latter species was a new species, not yet described ('Limnon') and sympatric with D. matsakisi from north Peloponnesus. Clade E included insular species from Crete, Naxos, Samos and Kalimnos islands (D. paraskevi, D. naxia and three new species, 'Parnaso', 'Crete' and 'East Aegean'; Fig. 1). Also in this case the two clades are strongly supported, with BP values ranging from $83 \%$ to $100 \%$ and PP values ranging from $90 \%$ to 99\%. Dolichopoda sbordonii from Anatolia was the most differentiated species.

Generally, species phylogenetically close were also geographically close (Mantel test: $r=0.287 ; \alpha<0.05$ ), except for a few species included in clades $\mathrm{C}$ and $\mathrm{D}$. In clade $\mathrm{C}$ a mix of southern and northern species could be found and in clade D the southernmost species, D. unicolor, was the sister taxon of the new species ('Limnon') from north Peloponnesus but not of $D$. paraskevi from Crete Island, as suggested by traditional taxonomy. Therefore, a set of alternative trees, suggested by traditional taxonomy were compared to our overall optimal tree by means of AU and SH likelihood ratio tests (Shimodaira \& Hasegawa, 1999; Shimodaira, 2002). Ten of the 11 suboptimal trees could be rejected in favour of our optimal tree using both $\mathrm{AU}$ and $\mathrm{SH}$ tests. In particular, topologies considering clade $\mathrm{C}$, with the exclusion of the central-western species D. lustriae as sister relative to the other species from Peloponnesus or D. lustriae as sister of the other centralwestern species (clade B) or 'Taygeto' as sister relative to the southernmost species $D$. unicolor, are rejected by both AU and SH tests in favour of our optimal tree $(P<0.005$, in all cases). Other topologies considering different positions of $D$. sbordonii, as sister of Crete Island or of Samos/Kalimnos islands ('East-Aegean') or of Naxos Island species or basal to western and northern species, were also rejected in favour of our optimal tree $(P<0.005$, in all cases). The placement of $D$. paraskevi as sister relative to $D$. unicolor from the south Peloponnesus was the one topology slightly supported by the AU test $(P=0.077)$.

\section{Dating of the cladogenetic events}

Dating estimates from the three data sets (COI, 12S/16S genes and concatenated data) overlapped entirely, indicating that radiation within the ingroup occurred $9 \mathrm{Ma}$ (Fig. 2).

The data showed a non-clock-like behaviour, with a coefficient of variation of 0.369 (95\% highest posterior density, HPD: $0.214-0.544)$ for COI and of 0.379 (95\% HPD: $0.154-0.624)$ for $12 S$ and $16 S$ genes. In none of the data sets did we find any evidence of autocorrelation of substitution rates (mean covariance 0.008, 95\% HPD -0.197/ 0.218 for COI; mean covariance 0.02 , 95\% HPD -0.189 / 0.227 for $12 \mathrm{~S} / 16 \mathrm{~S})$.

\section{Test of biogeographical hypotheses}

We tested hypotheses about the colonization of the Hellenic Peninsula by comparing the degree of discordance between species trees and gene trees. All tested hypotheses are consistent with most unambiguous features of our phylogenetic reconstruction, so that species trees only differed by essential predictions of each biogeographical scenario. The divergence of the Anatolian outgroup D. sbordonii from the 


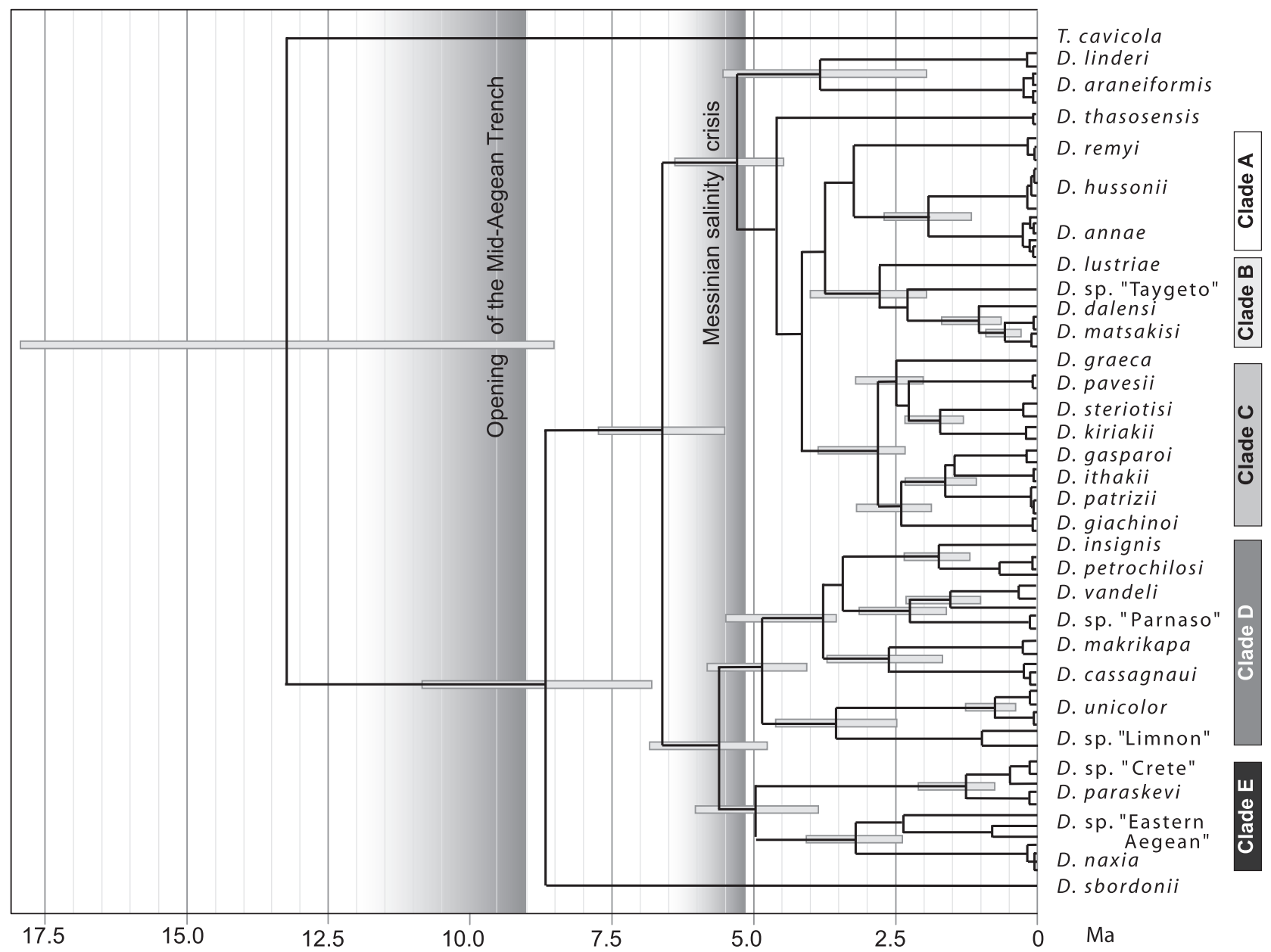

Figure 2 Divergence times among Greek species of Dolichopoda inferred by Bayesian analysis using a relaxed molecular clock. Bars at the nodes represent the $95 \%$ highest posterior density (HPD) credibility interval.

Hellenic species was always set to $9 \mathrm{Ma}(4,500,000$ generations); all events implying trans-Aegean dispersal were placed within the Messinian salinity crisis; divergence times of 'terminal' monophyletic clades were set as close as possible to the median value from the stationary phase of the BEAST MCMC analysis.

Four different hypotheses were considered (Fig. 3), as follows.

1. H1: all Greek Dolichopoda species originate from a single Messinian colonization from Anatolia through the Aegean. In this scenario, species occupying Aegean islands are basal to continental species.

2. H2: all Greek Dolichopoda species originate from a single colonization from Anatolia, through the present-day Bosporus. Aegean species must have split more recently than northern continental species, migrating to their island homelands during the Messinian marine regression.

3. H3: the opening of the Mid-Aegean Trench caused permanent isolation of Anatolian species (D. sbordonii) from Hellenic and Aegean species. The latter two colonized their present Greek range following two separate routes: some species expanded north, ascending the Hellenic Peninsula, while others expanded south and east, crossing the Aegean during the Messinian salinity crisis. In this scenario, northern Greek and western Mediterranean species (D. annae, D. hussonii, D. remyi, D. thasosensis, D. linderi, D. araneiformis) must form a monophyletic species group.

4. H4: Greek species originate from two independent Messinian dispersals from Anatolia. The ancestors of Aegean and southern Hellenic species spread through the Aegean Basin, while northern and western species followed a colonization route through the present-day Bosporus, heading west and south to the Peloponnesus. Under this hypothesis, northern Greek and western Mediterranean species must be basal to Ionian and north-eastern Peloponnesian species, while Aegean species must be basal to south-eastern Hellenic and south-western Peloponnesian species.

Hypotheses $\mathrm{H} 1$ and $\mathrm{H} 2$ were rejected under both assumed effective female population sizes (10,000 and 50,000), as none of the 5000 Bayesian trees fell within the simulated distribution (Fig. 3). H3 was rejected under the assumption of $N_{\mathrm{f}}=10,000$, though retained a marginal credibility when the very conservative $N_{\mathrm{f}}=50,000$ was assumed (overlap of simulated and inferred deep coalescence distribu- 

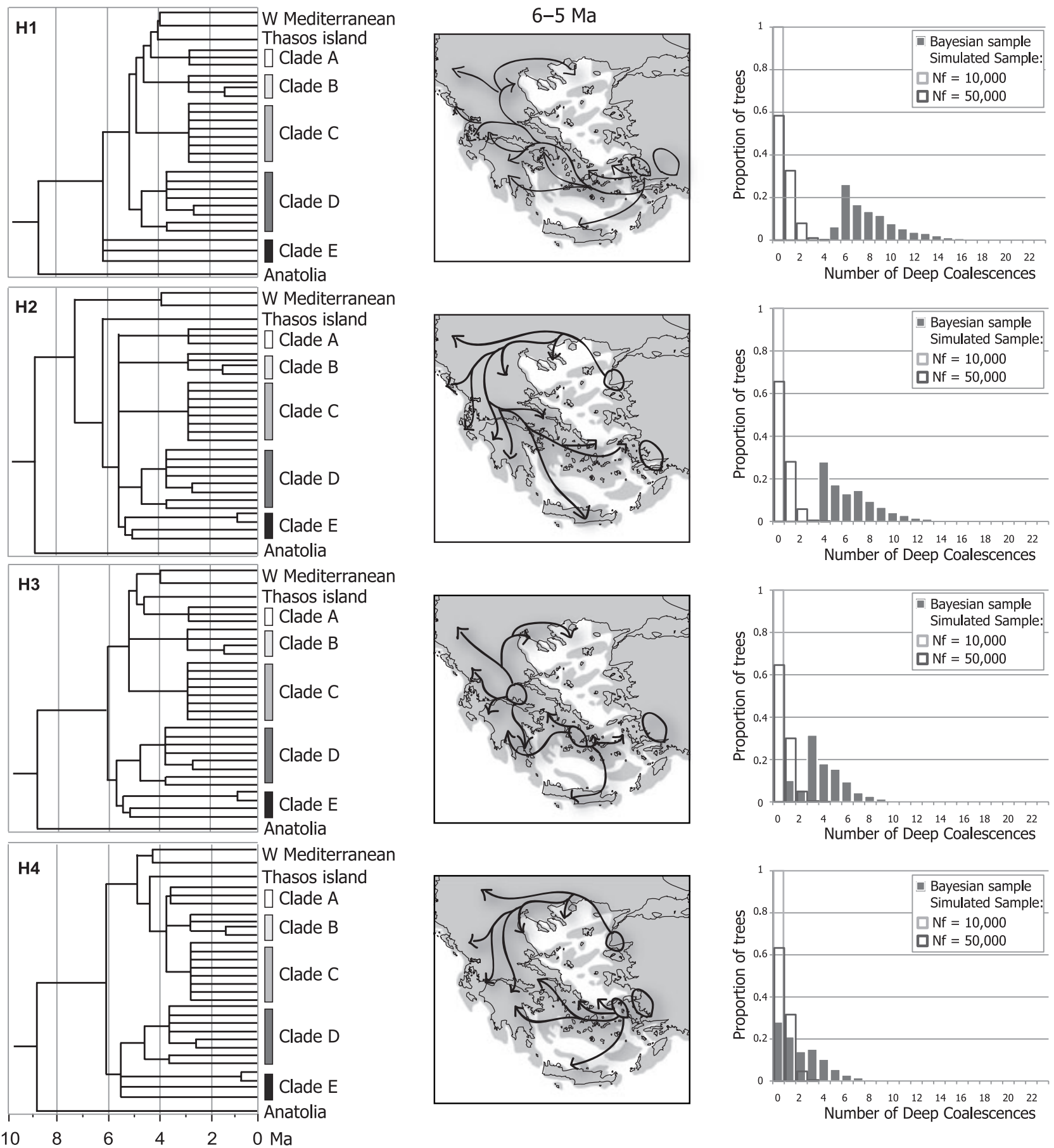

Figure 3 Testing the biogeographical hypotheses of the colonization of the Hellenic Peninsula by species of Dolichopoda. Species tree and palaeogeographical maps describing the four different biogeographical hypotheses (H1-H4) tested are shown in the left and central panels. Maps are redrawn after Dermitzakis \& Papanikolaou (1981) and Dermitzakis (1990). Contour lines refer to the current map of Greece, while the shadowed areas refer to palaeo-Greece. The right panel shows the distribution of deep coalescences in 1000 simulated trees (under effective female population size $\left(N_{\mathrm{f}}\right)=10,000$ and 50,000) and in Bayesian samples of 5000 trees. The clades are named as in Figs 2 and 3 and include the same species in the same order.

tions $=0.15)$. The only hypothesis that could not be rejected under both population sizes was H4, with $1406(0.28)$ and 2714 (0.54) trees overlapping the simulated distribution under $N_{\mathrm{f}}=10,000$ and $N_{\mathrm{f}}=50,000$, respectively. Thus, our analysis showed that a double colonization of the Hellenic Peninsula should be assumed in order to account for the present distribution of Greek species of Dolichopoda and their mtDNA variation. 


\section{DISCUSSION}

\section{Phylogenetic analysis}

The results of the present study reveal a rather well-resolved phylogeny at the species level, identifying a number of clades that represent long-separated lineages and diverse evolutionary histories within the genus Dolichopoda. The tree in Fig. 1 shows two main groups, one including the north-western species and the other one the southeastern species. Well-defined clades, constituted by geographically close species, strongly supported by BP and PP values and by the Mantel test could be distinguished, especially in the south-eastern group of species. Within the north-western group of species (clades A-C in Fig. 1), phylogeographical pattern was partially concealed by the unexpected composition of clade B. Within this clade, Dolichopoda species from north Peloponnesus (D. matsakisi and D. dalensi) and south Peloponnesus (D. sp. 'Taygeto') form a well-supported subclade linked to D. lustriae from the Valtou Mountains (Etolia, Akarnania) in central-western Greece $(\mathrm{BP}$ value $=94 \%$, PP value $=0.98)$. These results along with the AU test falsified the hypotheses (1) of D. lustriae as a sister taxon of the Ionian species in clade C, and (2) of D. sp. 'Taygeto' as sister taxon of the southernmost species, D. unicolor. Although these results were biogeographically unexpected, they agreed with traditional taxonomy. Dolichopoda lustriae is a recently described species (Rampini et al., 2008), sharing some morphological characters with $D$. dalensi and D. matsakisi from north Peloponnesus, which, in turn, share several morphological similarities with the Ionian species group. Other molecular phylogenetic studies on organisms distributed within continental and insular Greece have revealed phylogeographical patterns that partly coincide with the present study. Klossa-Kilia et al. (2006), in studying phylogenetic relationships in species of the isopod genus Ligidium (Isopoda, Oniscidea), found high similarity among populations from central continental Greece, the Ionian Islands and the Peloponnesus.

Also in the south-eastern group of species we observed an unexpected result from a biogeographical point of view. The sister taxon of $D$. unicolor from south Peloponnesus was D. sp. 'Limnon', a new species not yet described, which is sympatric with $D$. matsakisi from the Ton Limnon cave in north Peloponnesus. This result was also confirmed by the AU test that falsified the hypothesis of $D$. sp. 'Limnon' as sister taxon of the northern Peloponnesus species.

Relationships among different clades were not always resolved. This may be due to a nearly simultaneous origin of some lineages, indicated by comparatively short internodes (Figs 2 and 3). Similar patterns have been already observed in other invertebrate taxa of the Aegean Archipelago (Parmakelis et al., 2005; Klossa-Kilia et al., 2006).

\section{Reconstructing the evolutionary history of Dolichopoda in the eastern Mediterranean}

The tree topology and the estimated divergence times argue for a late Miocene deep cladogenesis of the Greek Dolichopoda species, and for an eastern (Anatolian) origin of the two main lineages in Fig. 1. This result appears to be consistent with fossil evidence that suggested a high migration flow of steppe elements from Asia Minor to Greece, during the late Miocene. During that period the former Aegean mainland formed an archipelago with several land bridges between Anatolia and Greece (Dermitzakis, 1990).

The estimated divergence time of the Greek lineages from the Anatolian D. sbordonii spans from 6.8 to $10.9 \mathrm{Ma}(95 \%$ HPD, mean $=8.6$; Fig. 2). This estimate is consistent with both the rise of Anatolian Plateau (5-10 Ma) and the formation of the Mid-Aegean Trench (which started $12 \mathrm{Ma}$ and was completed $9 \mathrm{Ma}$ ). The Mid-Aegean Trench separated the eastern Aegean islands and Asia Minor from the Cyclades and mainland Greece (Dermitzakis \& Papanikolaou, 1981). This event has been proposed as a major factor acting on the speciation of other different taxa, such as reptiles (Poulakakis et al., 2003, 2005), tenebrionid beetles (Fattorini, 2002), isopods (Sfenthourakis, 1996; Klossa-Kilia et al., 2006), scorpions (Parmakelis et al., 2006a,b) and land snails (Parmakelis et al., 2005). Nonetheless, our biogeographical hypotheses test rejected the scenario of the Mid-Aegean Trench triggering vicariance between Anatolian D. sbordonii and Hellenic species (H3 in Fig. 3). In fact, the most supported hypothesis implies that the ancestors of present Hellenic Dolichopoda diverged from D. sbordonii within Asia Minor (H4, Fig. 3). Our estimate of divergence time suggests that this earlier cladogenesis may be associated with the uplift of the Anatolian Plateau, which arose 5-10 Ma due to the acceleration of the northward movement of the Arabian Plate (Quennell, 1984; Steininger \& Rögl, 1984).

The divergence of the major clades in Fig. 2 falls within the Messinian salinity crisis. The Messinian was a time of high rainfall and high sediment yield rates. This period, named the Zeit Wet Phase, stands in marked contrast to the arid conditions of the preceding Tortonian Stage (Griffin, 1999). The desiccation of the Mediterranean Basin during the Messinian salinity crisis (Hsü, 1972; Hsü et al., 1977), 5.96$5.33 \mathrm{Ma}$ (Krijgsman et al., 1999), probably allowed broad land connections between formerly separated Aegean land masses. Results from biogeographical hypotheses tests (H4 in Fig. 3) suggested that radiation of the genus Dolichopoda in this area may have been promoted by the combination of low sea level and relatively humid climate occurring during the Messinian and favouring regional dispersal. The end of the Messinian salinity crisis seems also to be the main factor responsible for the speciation of the lineages in clades $\mathrm{D}$ and $\mathrm{E}$. The isolation of the Cretan species (clade E, Fig. 2) has been estimated at 4.9 Ma (95\% HPD 3.9, 6.0), roughly coinciding with the end of Messinian salinity crisis. After this period Crete became permanently isolated and the speciation of D. paraskevi 
started, as suggested by our divergence time estimates. The occurrence in Crete of two species, as suggested by both morphology (M. Rampini, unpublished data) and COI genetic differentiation, could have been caused by vicariance events favoured by climatic changes occurring around the PlioPleistocene boundary. Moreover, during the Pliocene, Crete consisted of several islands and its present shape was attained during the Pleistocene (Dermitzakis \& Papanikolaou, 1981).

The relatedness of the two new, undescribed species from the easternmost Aegean islands (clade E, Samos and Kalimnos) could be associated with their established palaeogeographical relationships, since both were connected to continental Asia Minor until recently in the Pleistocene (Perissoratis \& Conispoliatis, 2003). Their divergence time dates back to the end of the Pliocene and the beginning of the Pleistocene (Fig. 2). The sister taxon of these two species is D. naxia from Naxos, whose isolation started earlier, i.e. 3.14 Ma (95\% HPD 2.2, 4.1). This dating coincides with the separation of the southern Cyclades from the northern Cyclades plateau dated at 3.5 Ma (Anastasakis \& Dermitzakis, 1990), suggesting that D. naxia probably represents an older lineage of eastern origin.

The drastic climatic changes during the Pliocene towards a cooler and arid climate in the Mediterranean seem to be responsible for the subsequent divergence of the lineages within each clade. Moreover, the most recent species divergence seems to have been shaped by the repeated changes between marine regressions and transgressions during the PlioPleistocene. These events might have favoured dispersal and allopatric separation, especially of the insular species. This can be observed in clade $\mathrm{C}$, where the divergence time estimates range from 1.6 to $2.4 \mathrm{Ma}$ (95\% HPD 1.1, 2.3 and 1.9, 2.6, respectively).

The radiation of clade $B$, comprising different lineages from the western mainland Greece (Etolia, D. lustriae), the south Peloponnesus (D. sp. 'Taygeto') and the north Peloponnesus (D. matsakisi) was estimated to have started $2.8 \mathrm{Ma}$ (95\% HPD 2.0, 4.0), during the later early Pliocene. The links of these geographically distant lineages imply that these regions maintained some connection during that time. The isolation of Peloponnesus ended approximately $3 \mathrm{Ma}$ (Dermitzakis, 1990). The union with mainland Greece could have favoured the dispersal between nearby populations and a stepping-stone gene flow between those more distant. As within clade B, two geographically distant species are phylogenetically related in clade D. In fact, D. unicolor from south Peloponnesus is the sister taxon of D. sp. 'Limnon' from north Peloponnesus. We could hypothesize, as before, stepping-stone gene flow between distant populations following different routes from those used by lineages in clade B. This pattern has probably been driven by variable elevations to which different species are adapted. Indeed in clade $B$, both $D$. lustriae and $D$. sp. 'Taygeto' inhabit caves situated at about $2000 \mathrm{~m}$ a.s.l., while D. unicolor and D. sp. 'Limnon' live at lower elevations. Therefore, we could interpret these two lineages as tracking the past high- and/ or low-elevation colonization.
In conclusion, both phylogenetic reconstruction and the results of the biogeographical hypotheses tests (Fig. 3) indicate that the colonization of Greece by Dolichopoda species followed two different routes, probably originating in Anatolia. The southern lineage, including species currently inhabiting the Aegean Islands, Crete, south-eastern Greece and southwestern Peloponnesus, probably arose from a trans-Aegean colonization during the Messinian salinity crisis (5.96-5.33 Ma; Fig. 2). The northern lineage, currently occurring in the western Mediterranean, Thasos Island, northern Greece, Ionian Islands, and north-eastern Peloponnesus, could be the result of dispersal from the north through the Balkan Peninsula. In this reconstructed scenario the opening of the Mid-Aegean Trench would have promoted an initial diversification within the uprising Anatolian Plateau, while the Messinian marine regression offered the conditions for a rapid dispersal through the whole Aegean-Hellenic region. In addition, climatic events during the Plio-Pleistocene may have been responsible for the speciation within each of the two different phylogeographical units, mainly driven by vicariance events. This hypothesis is also supported by results from the western Mediterranean species whose radiation also appears to have followed the climatic changes of the Plio-Pleistocene (Allegrucci et al., 2005).

\section{ACKNOWLEDGEMENTS}

We are grateful to Anna Fabiani, Gabriele Gentile and Conrad C. Labandeira who provided useful criticisms on a previous version of the paper and to Michele Scardi for his valuable advice on statistical analyses. P. M. Giachino, D. Vailati, F. Gasparo and P. Marcia helped us in collecting samples. This research was financially supported by PRIN (the Italian Program for Relevant National Researches) grant to Valerio Sbordoni.

\section{REFERENCES}

Allegrucci, G., Todisco, V. \& Sbordoni, V. (2005) Molecular phylogeography of Dolichopoda cave crickets (Orthoptera, Rhaphidophoridae): a scenario suggested by mitochondrial DNA. Molecular Phylogenetics and Evolution, 37, 153-164.

Anastasakis, G.C. \& Dermitzakis, M. (1990) Post-Middle Miocene palaeogeographic evolution of the Central Aegean Sea and detailed Quaternary reconstruction of the region. Its possible influence on the distribution of the Quaternary mammals of the Kyklades Islands. Neues Jahrbuch für Geologie und Paläontologie- Abhandlungen, 1, 1-16.

Beerli, P., Hotz, H. \& Uzzell, T. (1996) Geologically dated sea barriers calibrate a protein clock for Aegean water frogs. Evolution, 50, 1676-1687.

Boudou-Saltet, P. (1980) Les Dolichopodes (Orth., Rhaph.) de Grèce IX. Une espèce nouvelle en Eubée: D. makrykapa. Biologia Gallo-Hellenica, 9, 123-134.

Brower, A.V.Z. (1994) Rapid morphological radiation and convergence among races of the butterfly Heliconius hereto 
inferred from patterns of mitochondrial DNA evolution. Proceedings of the National Academy of Sciences USA, 91, 6491-6495.

Buckley, T.R., Simon, C. \& Chambers, G.K. (2001) Phylogeography of the New Zealand cicada Maoricicada campbelli based on mitochondrial DNA sequences: ancient clades associated with Cenozoic environmental change. Evolution, 55, 1395-1407.

Caccone, A. \& Sbordoni, V. (2001) Molecular biogeography of cave life: a study using mitochondrial DNA from Bathysciinae beetles. Evolution, 55, 122-130.

Carchini, G., Rampini, M., Severini, C. \& Sbordoni, V. (1983) Population size estimates of four species of Dolichopoda in natural and artificial caves of central Italy (Orth. Raph.). Mémoires de Biospéologie, 10, 341-347.

Chopard, L. (1936) Biospeleologica N. LXIII. Orthopteres et Dermaptéres (Premiere serie). Archives de Zoologie Experimentale et Generale, Paris, 78, 195-214.

Dermitzakis, D.M. (1990) Paleogeography, geodynamic processes and event stratigraphy during the late Cenozoic of the Aegean area. International Symposium on Biogeographical Aspects of Insularity, Roma 1987, Accademia Nazionale dei Lincei, 85, 263-288.

Dermitzakis, M.D. \& Papanikolaou, D.J. (1981) Paleogeography and geodynamics of the Aegean region during the Neogene. Seventh International Congress on Mediterranean Neogene, Athens. Annals of Geology Pays Hellen, 30, 245-289.

Di Russo, C. \& Sbordoni, V. (1998) Gryllacridoidea. Encyclopaedia Biospeologica, 2, 979-988.

Di Russo, C., Vellei, A., Carchini, G. \& Sbordoni, V. (1987) Life cycle and age structure of Dolichopoda populations (Orthoptera, Rhaphidophoridae) from natural and artificial cave habitats. Bollettino di Zoologia, 54, 337-340.

Douris, V., Cameron, R.A.D., Rodakis, G.C. \& Lekanidou, R. (1998) Mitochondrial phylogeography of the land snail Albinaria in Crete: long-term geological and short-term vicariance effects. Evolution, 52, 116-125.

Doyle, J.J. \& Doyle, J.L. (1987) A rapid DNA isolation procedure for small quantities of fresh leaf tissue. Phytochemical Bulletin, 19, 11-15.

Drummond, A.J. \& Rambaut, A. (2007) BEAST v1.4.7. Bayesian Evolutionary Analysis Sampling Trees. Computer program. Available at: http://beast.bio.ed.ac.uk/ (last accessed April 2008).

Drummond, A.J., Ho, S.H.W., Phillips, M.J. \& Rambaut, A. (2006) Relaxed phylogenetics and dating with confidence. PLoS Biology, 4, 699-710.

Farris, J.S. (1970) Methods for computing Wagner trees. Systematic Zoology, 18, 374-385.

Farris, J.S., Källersjö, M., Kluge, A.G. \& Bult, C. (1994) Testing significance of incongruence. Cladistics, 10, 315-319.

Farris, J.S., Källersjö, M., Kluge, A.G. \& Bult, C. (1995) Constructing a significance test for incongruence. Systematic Biology, 44, 570-572.

Fattorini, S. (2002) Biogeography of the tenebrionid beetles (Coleoptera, Tenebrionidae) on the Aegean Islands (Greece). Journal of Biogeography, 29, 49-67.
Gorochov, A.V. (2001) The higher classification, phylogeny and evolution of the superfamily Stenopelmatoidea. The biology of wetas, king crickets and their allies (ed. by L.H. Field), pp. 3-33. CABI, Wallingford, UK.

Griffin, D.L. (1999) The late Miocene climate of northeastern Africa: unravelling the signals in the sedimentary succession. Journal of the Geological Society, 156, 817-826.

Gu, X., Fu, Y.X. \& Li, W.H. (1995) Maximum likelihood estimation of heterogeneity of substitution rate among nucleotide sites. Molecular Biology and Evolution, 12, 546-557.

Hsü, K.J. (1972) Origin of saline giants: a critical review after the discovery of the Mediterranean evaporates. Earth-Science Reviews, 8, 371-396.

Hsü, K.J., Montadert, L., Bernoulli, D., Cita, M.B., Erickson, A., Garrison, R.E., Kidd, R.B., Mèlierés, F., Müller, C. \& Wright, R. (1977) History of the Messinian salinity crisis. Nature, 267, 399-403.

Hubbell, T.H. \& Norton, R.M. (1978) The systematics and biology of the cave-crickets of the North American tribe Hadenoecinni (Orthoptera Saltatoria: Rhaphidophoridae: Dolichopodinae). Miscellaneous Publications, Museum of Zoology, University of Michigan, 156, 1-125.

Huelsenbeck, J.P. \& Crandall, K.A. (1997) Phylogeny estimation and hypothesis testing using maximum likelihood. Annual Review of Ecology and Systematics, 28, 437-466.

Jobb, G., von Haeseler, A. \& Strimmer, K. (2004) TREEFINDER: a powerful graphical analysis environment for molecular phylogenetics. BMC Evolutionary Biology, 4, 18-27.

Klossa-Kilia, E., Kilias, G., Tryfonopoulos, G., Koukou, K., Sfenthourakis, S. \& Parmakelis, A. (2006) Molecular phylogeny of the Greek populations of the genus Ligidium (Isopoda, Oniscidea) using three mtDNA gene segments. Zoologica Scripta, 35, 459-472.

Kluge, A.G. \& Farris, J.S. (1969) Quantitative phyletics and the evolution of anurans. Systematic Zoology, 18, 1-32.

Kocher, T.D., Thomas, W.K., Meyer, A., Edwards, S.V., Paabo, S., Villablanca, F.X. \& Wilson, A.C. (1989) Dynamics of mitochondrial DNA evolution in animals: Amplification and sequencing with conserved primers. Proceedings of the National Academy of Sciences USA, 86, 6196-6200.

Krijgsman, W. (2002) The Mediterranean: Mare Nostrum of Earth sciences. Earth and Planetary Science Letters, 205, 1-12.

Krijgsman, W., Hilgen, F.J., Ray, I., Sierro, F.J. \& Wilson, D.S. (1999) Chronology, causes and progression of the Messinian salinity crisis. Nature, 400, 652-655.

Lanave, C., Preparata, C., Saccone, C. \& Serio, G. (1984) A new method for calculating evolutionary substitution rates. Journal of Molecular Evolution, 20, 86-93.

Leroy, Y. (1967) Gryllides et grillacrides cavernicoles. Annales de Speologie, 22, 659-722.

Lunt, D.H., Zhang, D.X., Szymura, J.M. \& Hewitt, G.M. (1996) The insect cytochrome oxidase I gene: evolutionary patterns and conserved primers for phylogenetic studies. Insect Molecular Biology, 5, 153-165.

Maddison, W.P. (1997) Gene trees in species trees. Systematic Biology, 46, 523-536. 
Maddison, W.P. \& Maddison, D.R. (2008) Mesquite: a modular system for evolutionary analysis. Version 2.5. Available at: http://mesquiteproject.org (last accessed April 2008).

Mantel, N. (1967) The detection of disease clustering and a generalized regression approach. Cancer Research, 27, 209220.

Oliverio, M., Bologna, A.M. \& Mariottini, P. (2000) Molecular biogeography of the Mediterranean lizards Podarcis Wagler, 1830 and Teira Gray, 1838 (Reptilia, Lacertidae). Journal of Biogeography, 27, 1403-1420.

Palumbi, S.R. (1996) Nucleic acids II: the polymerase chain reaction. Molecular Systematics (ed. by D.H. Hillis, C. Moritz and B.K. Mable), pp. 205-248. Sinauer, Sunderland, MA.

Parmakelis, A., Pfenninger, M., Spanos, L., Papagiannakis, G., Louis, C. \& Mylonas, M. (2005) Inference of a radiation in Mastus (Gastropoda, Pulmonata, Enidae) on the island of Crete. Evolution, 59, 991-1005.

Parmakelis, A., Stathi, I., Chatzaki, M., Simaiakis, S., Spanos, L., Louis, C. \& Mylonas, M. (2006a) Evolution of Mesobuthus gibbosus (Brullé, 1832) (Scorpiones: Buthidae) in the northeastern Mediterranean region. Molecular Ecology, 15, 2883-2894.

Parmakelis, A., Stathi, I., Spanos, L., Louis, C. \& Mylonas, M. (2006b) Phylogeography of Iurus dufoureius (Brullé, 1832) (Scorpiones, Iuridae). Journal of Biogeography, 331, 251-260.

Perissoratis, C. \& Conispoliatis, N. (2003) The impacts of sealevel changes during latest Pleistocene and Holocene times on the morphology of the Ionian and Aegean seas (SE Alpine Europe). Marine Geology, 196, 145-156.

Posada, D. \& Crandall, K. (1998) MODELTEST: testing the model of DNA substitutions. Bioinformatics, 14, 817-818.

Poulakakis, N., Lymberakis, P., Antoniou, A., Chalkia, D., Zouros, E., Mylonas, M. \& Valakos, E. (2003) Molecular phylogeny and biogeography of the wall-lizard Podarcis erhardii (Squamata: Lacertidae). Molecular Phylogenetics and Evolution, 28, 38-46.

Poulakakis, N., Lymberakis, P., Tsigenopoulos, C.S., Magoulas, A. \& Mylonas, M. (2005) Phylogenetic relationships and evolutionary history of snake-eyed skink Ablepharus kitaibelii (Sauria: Scincidae). Molecular Phylogenetics and Evolution, 34, 245-256.

Quennell, A.M. (1984) The western Arabia rift system. The geological evolution of the eastern Mediterranean. Geological Society Special Publications, No. 17 (ed. by J.E. Dixon and A.H.F. Robertson), pp. 775-778. Blackwell Science, Oxford.

Rambaut, A. \& Drummond, A.J. (2003) Tracer (computer program). Available at: http://evolve.zoo.ox.ac.uk/Evolve/ Software.html (last accessed April 2008).

Rampini, M., Di Russo, C., Pavesi, F. \& Cobolli, M. (2008) The genus Dolichopoda in Greece. A description of new species from the Ionian Regions and Peloponnisos (Orthoptera, Rhaphidophoridae). Zootaxa, 1923, 1-17.

Ronquist, F. \& Huelsenbeck, J.P. (2003) MrBayes 3: Bayesian phylogenetic inference under mixed models. Bioinformatics, 19, 1572-1574.
Sanderson, M.J. \& Donoghue, M.J. (1989) Patterns of variation in levels of homoplasy. Evolution, 43, 1781-1795.

Sfenthourakis, S. (1996) A biogeographical analysis of terrestrial isopods (Isopoda, Oniscidea) from central Aegean islands (Greece). Journal of Biogeography, 23, 687-698.

Sfenthourakis, S. \& Legakis, A. (2001) Hotspots of endemic terrestrial invertebrates in southern Greece. Biodiversity and Conservation, 10, 1387-1417.

Shimodaira, H. (2002) An approximately unbiased test of phylogenetic tree selection. Systematic Biology, 51, 492508.

Shimodaira, H. \& Hasegawa, M. (1999) Multiple comparisons of log-likelihoods with applications to phylogenetic inference. Molecular Biology and Evolution, 16, 1114-1116.

Shimodaira, H. \& Hasegawa, M. (2001) CONSEL: for assessing the confidence of phylogenetic tree selection. Bioinformatics, 17, 1246-1247.

Simon, C., Frati, F., Beckenbach, A., Crespi, B., Liu, H. \& Flook, P. (1994) Evolution, weighting and phylogenetic utility of mitochondrial gene sequences and a compilation of conserved polymerase chain reaction primers. Annals of the Entomological Society of America, 87, 651-701.

Steininger, F.F. \& Rögl, F. (1984) Paleogeography and palinspatic reconstruction of the Neogene of the Mediterranean and Paratethys. The geological evolution of the eastern Mediterranean. Geological Society Special Publications, No. 17 (ed. by J.E. Dixon and A.H.F. Robertson), pp. 659-668. Blackwell Science, Oxford.

Strid, A. (1997) Introduction. Flora Hellenica, Vol. 1 (ed. by A. Strid and K. Tan), pp. 9-35. Koeltz Scientific Books, Koenigstein.

Swofford, D. (2003) PAUP* Version 4.beta 10. Sinauer, Sunderland, MA.

Thompson, J.D., Gibson, T.J., Plewniak, F., Jeanmougin, F. \& Higgins, D.G. (1997) The CLUSTAL_X windows interface: flexible strategies for multiple sequence alignment aided by quality analysis tools. Nucleic Acids Research, 24, 4876-4882.

Yang, Z. (1994) Maximum likelihood phylogenetic estimation from DNA sequences with variable rates over sites: approximate methods. Journal of Molecular Evolution, 39, $306-314$.

\section{BIOSKETCHES}

Giuliana Allegrucci, Valerio Sbordoni and Mauro Rampini have considerable experience in the ecology and genetics of cave cricket populations. Valentina Todisco performed some of the laboratory work. Paolo Gratton developed the biogeographical hypothesis tests.

Editor: Melodie McGeoch 